Studia nad Autorytaryzmem i Totalitaryzmem 43, nr 3

Wrocław 2021

https://doi.org/10.19195/2300-7249.43.3.16

\author{
JUSTYNA BAZYLIŃSKA-NAGLER \\ ORCID: 0000-0002-0190-7566 \\ Uniwersytet Wrocławski \\ justyna.bazylinska-nagler@uwr.edu.pl
}

\title{
Partycypacja społeczna jako filar demokracji środowiskowej w Chińskiej Republice Ludowej
}

Słowa kluczowe: demokracja środowiskowa, partycypacja społeczna, społeczeństwo obywatelskie Chińskiej Republiki Ludowej, autorytaryzm, totalitaryzm, środowiskowe NGO's, Program zarządzania środowiskiem UE-Chiny.

\section{PUBLIC PARTICIPATION AS ONE OF THE ENVIRONMENTAL DEMOCRACY PILLARS IN THE PEOPLE'S REPUBLIC OF CHINA}

\begin{abstract}
The latest revision from 2014 of the Chinese Environmental Protection Law introduced a new mechanism of public participation in environmental law-making. It forces the Chinese legislative process to be more transparent and inclusive, that is to say - involve civil society and NGOs. Generally, this development deserves support and approval; there are, however, several shortcomings that should be addressed in the future. For instance, neither the level of cooperation between legislature and civil society nor the outcomes of public participation do always meet social expectations.

The purpose of this work was to research the Chinese model of public participation in environmental decision-making, bearing in mind the authoritarian governance of the People's Republic of China. Then, to analyze the real impact of the international cooperation and standards on the application of this model. Specifically, the EU-China Environmental Governance Programme (2010-2015) was discussed as a very influential example.

The outcome of the research shows that Chinese environmental law has been notably shaped by public international and European law. There are considerable similarities between the legal instruments of environmental democracy applied in China and public international law standards promoted by the United Nations and the European Union through the implementation of the Aarhus Convention of 1998. And, without doubt, it has to be recognised that the People's Republic of China has its own rich and diversified, however contradictory during the course of history, doctrines and a jurisprudence body of work considering civil society's participatory role in decision-making.
\end{abstract}


Each of the successive Chinese forms of government - beginning with despotism, then a glimpse of democracy, totalitarianism, and, finally, authoritarianism - did leave their mark on the Chinese political thought and law regarding the desired participation level of society (i.e. various civil movements and NGOs) in state affairs. In this day and age, social interest and support for the environmental protection is well-accepted by the Chinese government, especially due to the current plan of the Communist Party of China (CPC) to build an "ecological civilization" in China.

Keywords: environmental democracy, public participation, authoritarianism, totalitarianism, the People's Republic of China civil society, environmental NGOs, the EU-China Environmental Governance Programme.

\section{Społeczeństwo obywatelskie i organizacje pozarządowe w Chinach}

Cywilizację chińską od chrześcijańskiej cywilizacji Zachodu oddzielają głębokie i fundamentalne różnice kulturowe ${ }^{1}$. $Z$ tego też względu w Chinach wzorce zachodnie nie są traktowane jako oczywiście słuszne. Mają one swoich zwolenników, ale wielu uznaje je za mało przydatne dla Chin i zagrażające chaosem. Ku-Hung-Ming należał do tej wielkiej czwórki współczesnych filozofów na Wschodzie, którzy z całym sceptycyzmem odnosili się i odnoszą do naszej zachodniej cywilizacji, widząc, że stała się zbyt zmaterializowana. Zdaniem Ku-Hung-Minga kultura zachodnia zagraża dalszemu rozwojowi człowieka, prowadzi do upadku moralności, utraty wartości duchowych, które kierując jego życiem, mogą prowadzić do spokoju i osiągalnego szczęścia ${ }^{2}$.

Wiadomo jednak, że niektóre idee uznawane w Europie za demokratyczne — takie jak konieczność liczenia się ze zdaniem ludu w celu dążenia do społecznego konsensusu — nie były obce także myśli konfucjańskiej. Konfucjusz nauczał, że „kluczowym czynnikiem dla państwa jest zaufanie społeczeństwa do władzy, bez tego zaufania państwo musi upaść"3. Od starożytności można to traktować jako fundament demokratycznych idei państw z kręgu cywilizacji konfucjańsko-buddyjskiej. Stąd też uprawnione wydaje się stwierdzenie, że koncepcja społeczeństwa obywatelskiego w Chinach jest ważna i funkcjonuje tam od dawna. W swym

1 S. Huntington, The Clash of Civilizations?, „Foreign Affairs” 1993, nr 72 (3), s. 22-49.

2 Gu Hongming - wybitny chiński myśliciel przełomu XIX i XX wieku. Był przedstawicielem tej grupy intelektualistów, która twierdziła, że bezmyślna, a także zbyt szybka implementacja wzorców zachodnich jest niewykonalna i ostatecznie szkodliwa dla Chin. Gu wskazywał, że to konfucjanizm powinien pozostawać fundamentem moralności dla obywateli Państwa Środka. Da się go jednak połączyć z osiągnięciami zachodniej cywilizacji; więcej H. Gu, Duch narodu chińskiego, przeł. J. Targowski, Kraków 1928; M. Tylkowski, Gu Hongming prekursorem idei fuzji cywilizacji. Konfucjanizm jako ratunek dla Zachodu i świata, Warszawa 2021.

3 P. Dąbrowski, Myśl polityczno-prawna starożytnych Chin. Próba syntezy, „Gdańskie Studia Azji Wschodniej” 2012, nr 2, s. 5; M. Sadowski, Konfucjusz, [w:] Leksykon myślicieli politycznych i prawnych, red. E. Kundera, M. Maciejewski, Warszawa 2009, s. 25. 
podstawowym założeniu jest ona jednak zupełnie inna od europejskiej ${ }^{4}$. W krajach konfucjańskich ${ }^{5}$ podstawowym obowiązkiem obywatela jest harmonijna współpraca $\mathrm{z}$ państwem, z władzą lokalną, z rodem i w końcu z rodziną. Funkcjonuje bowiem ,ja" grupowe (ang. we-self, group-self) ${ }^{6}$. Struktury społeczne kształtowane w Chinach mają charakter kolektywny, co powoduje powstawanie „kultury kolektywnej", podczas gdy na Zachodzie przeważa podejście indywidualistyczne. Europejska oświeceniowa koncepcja wolności indywidualnej jednostki nie jest w Chinach powszechnie zrozumiała, a przez to nie jest społecznie pożądana. Samo słowo „wolność” zostało wprowadzone do języka chińskiego w XX wieku na potrzeby thumaczeń z języków zachodnich i po chińsku znaczy ,przyczyna we mnie"7. Także życie i śmierć, a przez to prawo do życia i pozostałe prawa człowieka wobec powszechnej wiary w reinkarnację, nabierają autonomicznego, kulturowo zdeterminowanego znaczenia ${ }^{8}$.

Udział w życiu publicznym nie leży w naturze Chińczyków ${ }^{9}$. Świadomość omnipotencji państwa i historyczna tradycja sprawowania władzy oraz urzędów przez wysoko wykwalifikowanych urzędników - mandarynów - sprawiły, że społeczeństwo instynktownie dystansuje się wobec spraw publicznych. Przez tysiąclecia w Azji Wschodniej przyjmowano, że ład społeczno-polityczny powinien opierać się na harmonii, współdziałaniu i konsensusie, nie zaś na charakterystycznych dla Zachodu współzawodnictwie czy równoważeniu sił antagonistycznych ${ }^{10}$.

${ }^{4}$ K. Gawlikowski, Formowanie społeczeństwa obywatelskiego w Chinach $w X X$ w. [w:] Chiny: rozwój spoleczeństwa i państwa na przełomie XX i XXI wieku, red. K. Gawlikowski, K. Tomala, Warszawa 2002.

${ }^{5}$ Wzorce i założenia modelu państwa konfucjańskiego przyjmowano w krajach ościennych takich, jak: Wietnam, Korea, Japonia, Singapur, a także w przejściowych formach państw: tanguckiego, kitańskiego, dżurdżeńskiego, mandżurskiego, Bohai czy też w sinitycznej Mongolii, za: K. Gawlikowski, Konfucjański model państwa w Chinach, Warszawa 2009, s. 8 n.

${ }^{6} \mathrm{~K}$. Gawlikowski, Zachodni indywidualizm a konfucjańska apoteoza grupy i tożsamości grupowej, „Azja-Pacyfik” 23, 2020, s. 36-76.

7 Ibidem.

8 Zgodnie z poglądem, jakim jest determinizm kulturowy — model społeczno-gospodarczy i polityczny państwa jest $\mathrm{w}$ dużym stopniu uwarunkowany wyznawanymi przez społeczeństwo wartościami kulturowymi, za: A. Sen, How does culture matter?, [w:] Culture and Public Action, red. V. Rao, M. Walton, Palo Alto 2004, s. 37-38; L.E. Harrison, Who Prospers? How cultural values shape economic and political success, New York 1992, passim. Przykładowo w języku chińskim słowo ,głupiec” znaczy: „ten, który boi się śmierci”. Przy założeniu, że człowiekowi dane jest nie jedno, ale kilka żyć, to sformułowanie nabiera zupełnie nowego dla Europejczyka znaczenia; por. K-H. Pohl, Life and Death in East and West - Montaigne's views on death compared to attitudes found in the Chinese tradition, „Azja-Pacyfik” 21, 2018, s. 221-232.

9 K. Gawlikowski, Indywidualizm a kolektywizm, Warszawa 1999; idem, Konfucjański model państwa..., s. 16.

${ }^{10} \mathrm{~K}$. Gawlikowski, The Western and the Confucian approaches to war: The universe based on struggle versus the universe based on harmony, [w:] China: Confucian Tradition - Towards the New Century, red. A.W. Jelonek, B.S. Zemanek, Kraków 2008, s. 19-40. 
Chińczycy określają swój ustrój mianem demokracji kolektywnej bądź chińskiej $^{11}$. Współczesne Chiny ustrojowo są już daleko od totalitarnych reżimów przeszłości. Totalitaryzm przestał tam istnieć wraz z końcem lat siedemdziesiątych $\mathrm{XX}$ wieku, a system autorytarny, który zastąpił komunizm, podlega nieustannym przemianom, przede wszystkim decentralizacji oraz pluralizacji, kojarzonym zwykle z demokracją ${ }^{12}$. Brakuje jednak demokratycznej tradycji oraz instrumentów budowy państwa obywatelskiego. Autorytarną strukturą strzegącą monopolu swojej władzy pozostaje Chińska Partia Komunistyczna. Ta „demokracja kontrolowana" jako paternalistyczna forma rządów (którą zwolennicy liberalnej demokracji na Zachodzie odrzucają jako anachroniczną i opresyjną) bywa też nazywana azjatycką drogą lub demokracją konfucjańską ${ }^{13}$. Jednopartyjny autorytaryzm chiński różni się od totalitaryzmu także w odniesieniu do relacji państwo-gospodarka. Obecnie, na płaszczyźnie teoretycznej, władze chińskie już nie kwestionują ich rozdzielności. Chiński autorytaryzm wydaje się właściwy tylko temu państwu i może tworzyć oddzielny model określany też mianem racjonalnego (oświeconego) autorytaryzmu bądź neoautorytaryzmu. W takim rozumieniu Chiny pozostają państwem niedemokratycznym ${ }^{14}$.

Odejście Chin od komunizmu drogą autorytarną zapewniło chińskiemu społeczeństwu wiele korzyści - znacznie zwiększono wolności obywatelskie i gospodarcze przy wyraźnym podniesieniu poziomu życia. Zdaniem Krzysztofa Gawlikowskiego:

Przemiany w Chinach od 1978 r., kiedy to oficjalnie zostały rozpoczęte tak zwane „reformy” (gaige) i „otwarcie kraju na świat” (kaifang), były wielekroć większe i bardziej radykalne niż zmiany dokonane w Polsce po 1989 r. W Chinach objęły one nie tylko sferę gospodarczą, polityczną i ideologiczną, ale i wiele innych dziedzin ${ }^{15}$.

Wtedy to, po raz pierwszy od trzech tysięcy lat, Deng Xiaoping (1904-1997) zaczął wprowadzać w Chinach system państwa prawa na wzór zachodni. Reformy te doprowadziły do „miękkiego systemu autorytarnego”, który z czasem stawał się coraz bardziej pluralistyczny i w coraz większym stopniu oparty na rządach prawa. W ciągu trzydziestu lat Chiny z zacofanego, peryferyjnego mocarstwa, kwestionującego cały ład międzynarodowy, stały się jednym z liderów współczesnego świata. Zmieniło się życie całego społeczeństwa, na oczach Chińczyków

11 Konstytucja Chińskiej Republiki Ludowej z dnia 4 grudnia 1982 roku, z późn. zm., art. 1, https://biblioteka.sejm.gov.pl/konstytucje-swiata-chiny/.

12 P.F. Landry, Decentralized Authoritarianism in China: The Communist Party's Control of Local Elites in the Post-Mao Era, Cambridge 2008.

13 A.W. Jelonek, Confucianism - Asian values and liberal democracy, [w:] China: Confucian Tradition - Towards the New Century, red. A.W. Jelonek, B.S. Zemanek, Kraków 2008, s. 51.

14 Ibidem; A.J. Nathan, Chinas Transition, New York 1998, passim.

15 K. Gawlikowski, Charakter i dynamika ,reform Deng Xiaopinga”, 4.06.2016, https://www. swps.pl/nauka-i-badania/materialy-ccaw/2445-charakter-i-dynamika-reform-deng-xiaopinga (dostęp: 3.08.2021). 
spełniło się marzenie Sun Yat-sena o „odrodzeniu Chin” (xin Zhongguo) śnione od początku XX wieku. Powróciła ich dawna potęga i ważne miejsce w międzynarodowej społeczności państw ${ }^{16}$.

Pod wpływem przyjmowania przez Chiny uniwersalnych ponadkulturowych wzorców międzynarodowych zmieniły się także relacje między państwem a społeczeństwem. Dzięki dwustronnej lub wielostronnej współpracy na poziomie międzyrządowym, a także na forum organizacji międzynarodowych, przede wszystkim ONZ, międzynarodowe organizacje pozarządowe jako globalni aktorzy społeczeństwa obywatelskiego zaczęły w Chinach odgrywać swoje role, podejmując lokalne wyzwania w korelacji lub współpracy z miejscowymi organizacjami. Dotarło wsparcie i darowizny dla chińskich organizacji pozarządowych ze strony zagranicznego biznesu. Rozwinęła się także działalność zagranicznego sektora non profit na terenie samych Chin.

Przełomowy wpływ na rozwój społeczeństwa obywatelskiego w Chinach miała IV Światowa Konferencja Kobiet zorganizowania pod auspicjami ONZ w 1995 roku w Pekinie ${ }^{17}$. To właśnie Konferencyjne Forum Organizacji Pozarządowych w Sprawach Kobiet wypromowało organizację pozarządową jako nowy typ organizacji społecznej w Chinach. Od tego czasu pojęcie „NGO” (non-governmental organization) weszło tam na stałe do publicznego dyskursu. Organizacje zakładane przez kobiety, jak również inne grupy społeczne, także typu GONGO (government-organized non-governmental organization), jak: All-China Women's Federation (ACWF), zaczęły nazywać siebie NGO's. W kolejnych latach po tej konferencji władze chińskie przyjęły wyważony kurs wobec organizacji pozarządowych, dzięki temu ich liczba zaczęła rosnąc ${ }^{18}$. W Chińskiej Republice Ludowej mamy obecnie zarejestrowanych ponad 700 tys. organizacji pozarządowych ${ }^{19}$. Rola, jaką odgrywają organizacje społeczne w budowaniu społeczeństwa obywatelskiego w Chinach, jest nie do przecenienia, właśnie ze względu na ,grupową tożsamość" Chińczyków, której przejawem jest zdolność do zabierania głosu tylko w ramach i w imieniu grupy. Jednocześnie trzeba podkreślić, że ruch społeczny wzrastający wokół kwestii środowiskowych ${ }^{20}$ jest przez władze chińskie

${ }^{16}$ Uważa się, że wstąpienie Chin do Światowej Organizacji Handlu 11 grudnia 2001 roku było kolejnym krokiem milowym w budowaniu kompleksowej i wielowymiarowej pozycji Chin w społeczności międzynarodowej, por. WTO successfully concludes negotiations on China's entry, https://www. wto.org/english/news_e/pres01_e/pr243_e.htm; Y. Tan, How the WTO changed China. The mixed legacy of economic engagement, https://www.foreignaffairs.com/articles/china/2021-02-16/how-wtochanged-china (dostęp: 3.08.2021).

17 https://www.un.org/en/conferences/women/beijing1995 (dostęp: 10.09.2021).

18 Sh. Shieh, S. Knutson, Special Report. The Roles and Challenges of International NGO's in China's Development, „China Development Brief”55, 2012, s. 8-10.

19 B. Kuhn, Changing spaces for civil society organisations in China, „Open Journal of Political Science" 2018, nr 8, s. 467-494.

20 Pierwszą chińską środowiskową organizacją pozarządową była Friends of Nature, oficjalnie zarejestrowana 31 marca 1994 roku jako Instytut Zielonej Kultury Międzynarodowej Akademii 
bardzo dobrze tolerowany, w przeciwieństwie do organizacji społecznych, których celem jest ochrona praw człowieka ${ }^{21}$. Jedną z zasad budowy nowej chińskiej „cywilizacji ekologicznej” jest promowanie społecznego udziału i nadzoru przez organizacje ekologiczne procesu decyzyjnego w obszarze ochrony środowiska ${ }^{22}$.

Zgodnie z art. 9 chińskiego Prawa ochrony środowiska z 2014 roku rządy ludowe na różnych szczeblach administracji lokalnej promują ochronę środowiska i wspierają oddolne organizacje środowiskowe, społeczne i wolontariuszy w ochronie środowiska. Celem jest realizowanie edukacji środowiskowej, w tym znajomości przepisów prawa, oraz kreowanie atmosfery zrozumienia wokół problemów ochrony środowiska. Wydziały edukacji i szkoły są zobowiązane do włączania ochrony środowiska do programów nauczania, tak aby kształtować świadomość problemów środowiskowych wśród uczniów. Nadzór społeczny nad naruszeniami degradującymi środowisko jest także promowany przez państwowe media, które realizują zadania związane $\mathrm{z}$ edukacją środowiskową ${ }^{23}$. Zgodnie $\mathrm{z}$ art. 58 chińskiego Prawa ochrony środowiska organizacje społeczne zajmujące się ochroną środowiska $\mathrm{w}$ interesie publicznym przynajmniej od pięciu lat, zarejestrowane w wydziale spraw społecznych rządu lokalnego i nienotowane za naruszenia prawa, mają legitymację procesową. Mogą one niezarobkowo wnosić skargi w interesie publicznym na działania, które zanieczyszczają środowisko, lub na konkretne szkody ekologiczne ${ }^{24}$.

Kultury Chińskiej podległy Ministerstwu Spraw Obywatelskich. Jej misją jest edukacja środowiskowa i tworzenie platformy partycypacji społecznej w decydowaniu o sprawach środowiska. Drugą znaczącą w kraju organizacją ekologiczną jest Nature University; http://www.fon.org.cn/ (dostęp: 12.08.2021).

21 R. Siu Inboden, China at the UN: Choking Civil Society, ,Journal of Democracy” 32, 2021, nr 3.

22 The Central Committee of the Communist Party of China and the State Council, Overall Plan for the Reform of Eco-Civilization System, 22.09.2015, http://english.www.gov.cn/policies/ latest_releases/2015/09/22/content_281475195492066.htm (dostęp: 18.08.2021).

${ }^{2} 3$ „Article 9: The people's governments at various levels shall strengthen environmental protection publicity and dissemination, encourage self-governing grassroot organizations, social organizations and environmental protection volunteers to carry out the publicity of environmental protection laws, regulations and knowledge, so as to facilitate a favorable atmosphere for environmental protection.

Educational departments and schools shall incorporate environmental protection knowledge into the curriculum of school education so as to cultivate the environmental protection awareness among students.

News media shall carry out the publicity of environmental protection laws, regulations and knowledge, and facilitate the exercise of public supervision on environmental violation activities [wyr. - J.B-N.]". Zob. The Environmental Protection Law of the People's Republic of China (24 April 2014), compiled by the EU - China Environmental Governance Programme, http://extwprlegs1.fao.org/docs/pdf/chn135947.pdf (dostęp: 28.06.2021).

${ }^{24}$ Ibidem; „Article 58: For activities that cause environmental pollution, ecological damage and public interest harm, social organizations that meet the following conditions may file litigation to the people's courts: (1) Have their registration at the civil affair departments 


\section{Standardy międzynarodowe demokracji środowiskowej w ChRL}

Przeciwstawne traktowanie azjatyckich i zachodnich wartości odcisnęło swoje piętno także na współpracy międzynarodowej Chin, prowadziło bowiem do licznych impasów w negocjacjach umów i porozumień międzynarodowych. Przykładowo, państwa azjatyckie w deklaracji z Bangkoku z 1993 roku, poprzedzającej Konferencję ONZ w Sprawie Praw Człowieka, w Wiedniu, oświadczyły, że nie zaakceptują końcowej deklaracji z tejże konferencji, jeśli prawa indywidualne jednostki zostaną tam postawione przed prawem społeczeństwa (jako zbiorowości) do życia w stabilnym społecznym i politycznym porządku ${ }^{25}$. Wychodząc naprzeciw tym antynomiom, Organizacja Narodów Zjednoczonych w 1998 roku wypracowała „zasadę dialogu między kulturami i cywilizacjami” jako podstawę ich pokojowej współpracy ${ }^{26}$.

Dopiero w latach dziewięćdziesiątych XX wieku standardy zarządzania środowiskiem ${ }^{27}$ stały się przedmiotem dwustronnej współpracy międzynarodowej między Unią Europejską a Chińską Republiką Ludową. Dialog na linii Chiny-UE w obszarze ochrony środowiska zapoczątkowany został w 1992 roku, a w 1996 utworzono pierwszą Grupę Roboczą UE-Chiny ds. Ochrony Środowiska. Z komunikatu Komisji Europejskiej z tego okresu wynika jednak, że współpraca ta miała bardzo wstępny charakter ${ }^{28}$. Dopiero w 2003 roku wraz z inauguracją Strategicznego

of people's governments at or above municipal level with sub-districts in accordance with the law; (2) Specialize in environmental protection public interest activities for five consecutive years or more, and have no law violation records. Courts shall accept the litigations filed by social organizations that meet the above criteria. The social organizations that file the litigation shall not seek economic benefits from the litigation [wyr. - J.B-N.]".

25 World Conference on Human Rights Report of the Regional Meeting for Asia of the World Conference on Human Rights, Bangkok, 29.03-2.04.1993, http://www.internationalhumanrightslex icon.org/hrdoc/docs/bangkokdeclaration.pdf (dostęp: 15.09.2021), pkt 8: „while human rights are universal in nature, they must be considered in the context of a dynamic and evolving process of international norm-setting, bearing in mind the significance of national and regional particularities and various historical, cultural and religious backgrounds [wyr. - J.B-N.]".

26 Por. UN Assembly Proclaims 2001 United Nations Year of Dialogue among civilizations, expressing determination to facilitate international discussion, Press Release GA/9497 53rd Meeting (AM) 4.11.1998, https://www.un.org/press/en/1998/19981104.ga9497.html (dostęp: 15.09.202).

27 Program Narodów Zjednoczonych ds. Środowiska (ang. United Nations Environment Programme, UNEP) definiuje zarządzanie środowiskiem jako: ,zasady, praktyki, polityki oraz instytucje, które kształtują sposób, w jaki człowiek odnosi się do środowiska, a bardziej precyzyjnie zarządzanie środowiskiem zajmuje się badaniem wpływu procesów regulacyjnych, mechanizmów i organizacji na ochronę środowiska”, za: Y. Yang, How do EU norms diffuse? Rule of law promotion in EU-China cooperation on environmental governance, ,Journal of European Integration” 39, 2017, nr 1, s. 65.

28 Communication from the Commission: Building a Comprehensive Partnership with China, Brussels, 25.03.1998, COM(1998) 181 final. 
Partnerstwa UE-Chiny ${ }^{29}$ trajektoria tych relacji nabrała kształtu. Strategiczny program współpracy między UE a Chinami uzgodniony w 2020 roku $^{30}$, a obowiązujący na kolejną dekadę, objął następujące obszary: pokój i bezpieczeństwo, dobrobyt, zrównoważony rozwój i kontakty międzyludzkie. Stosunki dwustronne między Chińską Republiką Ludową a Unią Europejską są utrzymywane na najwyższym szczeblu dzięki spotkaniom na corocznym szczycie UE-Chiny ${ }^{31}$.

Największy wpływ na kształt chińskiego prawa ochrony środowiska wywarł Program Zarządzania Środowiskiem UE-Chiny (ang. EU-China Environmental Governance project, dalej: EGP) zrealizowany w latach $2010-2015^{32}$. W jego ramach UE dofinansowała (kwotą $15 \mathrm{mln}$ euro) realizację 15 lokalnych projektów w Chinach, których celem było zbudowanie potencjału instytucjonalnego i wypracowanie dobrych praktyk, tak aby efektywnie zarządzać ochroną środowiska. Program EGP zbudowany był z czterech zakresów tematycznych: pierwszy dotyczył publicznego dostępu do informacji o środowisku, drugi - partycypacji społecznej w konsultacjach i podejmowaniu decyzji w sprawach środowiskowych, trzeci - dostępu do wymiaru sprawiedliwości w sprawach z zakresu ochrony środowiska, czwarty - aktywnego zaangażowania sektora prywatnego w ochronę środowiska. Nieprzypadkowo pierwsze trzy tematy idealnie odpowiadają zakresowi regulacji trójfilarowej konwencji z Aarhus ${ }^{33}$. Filar I konwencji stanowi bowiem prawo do informacji o środowisku (art. 4-5 konwencji), filar II to prawo partycypacji społecznej w podejmowaniu decyzji dotyczących ochrony środowiska (art. 6-8 konwencji), a III filarem jest prawo dostępu do wymiaru sprawiedliwości w sprawach środowiskowych (art. 9 konwencji) ${ }^{34}$. Te trzy prawa do: informacji, partycypacji i sprawiedliwości, będące filarami konwencji, są jednocześnie fundamentem demokracji środowiskowej w Europie ${ }^{35}$.

${ }^{29}$ D. Torney, O. Gippner, China: Deepening Cooperation on Climate and Environmental Governance, [w:] European Union External Environmental Policy. Rules, Regulation and Governance Beyond Borders, red. C. Adelle, K. Biedenkopf, D. Torney, Cham 2018, s. 278-279.

30 The EU-China 2020 Strategic Agenda for Cooperation, https://eeas.europa.eu/archives/ docs/china/docs/eu-china_2020_strategic_agenda_en.pdf (dostęp: 19.08.2021).

31 EU-China Summit: Defending EU interests and values in a complex and vital partnership - Press release by President Michel and President von der Leyen, https://www.consilium.europa.eu/ $\mathrm{pl} /$ press/press-releases/2020/06/22/eu-china-summit-defending-eu-interests-and-values-in-a-com plex-and-vital-partnership/ (dostęp: 19.08.2021).

$32 \mathrm{https}$ ///socialquality.org/projects/egp-project/ (dostęp: 19.08.2021); następcą tego programu jest EU-China Environment Project, https://www.clientearth.org/projects/eu-china-environmentproject/\#abouttheproject (dostęp: 16.08.2021).

33 Konwencja o dostępie do informacji, udziale społeczeństwa w podejmowaniu decyzji oraz dostępie do sprawiedliwości w sprawach dotyczących środowiska, sporządzona w Aarhus 25.06.1998 r., Dz.U. z 2003 r. Nr 78, poz. 706 (dalej: konwencja z Aarhus).

${ }^{34}$ UN Economic Commission for Europe, Convention on Access to Information, Public Participation in Decision-making and Access to Justice in Environmental Matters. The Aarhus Convention: An implementation guide, 2nd edition, 2014, s. 6-7.

35 Por. G. Bándi, Introduction into the concept of "environmental democracy", [w:] Environmental Democracy and Law, red. G. Bándi, Groningen-Amsterdam 2014, s. 3 n.; idem, The three pillars of environmental democracy in a European perspective, [w:] ibidem, s. $39 \mathrm{n}$. 
Konwencja z Aarhus jest postrzegana jako jedna z najbardziej ambitnych umów międzynarodowych w przedmiocie ochrony środowiska $\mathrm{z}$ tego względu, że przez przyznanie społeczeństwu konkretnych praw proceduralnych, w tym prawa dostępu do wymiaru sprawiedliwości w sprawach środowiskowych, umożliwia realizację prawa do życia $\mathrm{w}$ czystym środowisku ${ }^{36}$. Jest to umowa otwarta także dla państw spoza Europy, wśród 41 jej państw-stron 14 to państwa pozaeuropejskie $^{37}$. Trzeba też podkreślić, że konwencja z Aarhus jest pierwszym aktem prawnym, który kodyfikuje prawa proceduralne dotyczące ochrony środowiska, przenosi je z poziomu deklaracji politycznych na poziom wiążących zobowiązań prawnomiędzynarodowych w celu upowszechnienia i realizacji standardów demokracji środowiskowej ${ }^{38}$. Jako że były one wcześniej przedmiotem szeroko zakrojonych prac ONZ, przypisuje się im charakter uniwersalny raczej niż stricte europejski. Taką uniwersalną zasadą zawierającą elementy konstytutywne demokracji środowiskowej, adresowaną do wszystkich państw ONZ, jest zasada 10 Deklaracji z Rio w sprawie Środowiska i Rozwoju z 1992 roku:

\begin{abstract}
Zagadnienia środowiskowe są na każdym poziomie najlepiej rozwiązywane przy udziale wszystkich zainteresowanych obywateli. Na poziomie państwa każdy obywatel powinien mieć zapewniony odpowiedni dostęp do informacji dotyczącej środowiska, która jest w posiadaniu władzy publicznej. Dotyczy to informacji o niebezpiecznych substancjach i o niebezpiecznej działalności w rejonie zamieszkiwania społeczności, jak również możliwości uczestniczenia społeczeństwa w procesie podejmowania decyzji. Państwa powinny to ułatwić, jak również zwiększyć świadomość społeczeństwa przez stworzenie szerokiego dostępu do informacji. Powinien zostać zapewniony efektywny i rzeczywisty dostęp do prawnych i administracyjnych środków w tym zakresie, włączając w to środki kompensujące i zaradcze [wyr. - J.B.-N.] $]^{39}$.
\end{abstract}

Za pomocą Programu Zarządzania Środowiskiem UE-Chiny, o którym tutaj mowa, przeniesiono do Chin wzorce zarządzania środowiskiem i standardy demokracji środowiskowej wypracowane przez ONZ, a następnie skodyfikowane w konwencji z Aarhus. Przykładowo, zwraca uwagę podobieństwo przepisów rozdziału 5 chińskiej ustawy o ochronie środowiska: ,w sprawie publicznego dostępu do informacji środowiskowej oraz udziału społeczeństwa w podejmowaniu decyzji dotyczących środowiska", oraz odpowiednich, wskazanych wcześniej, przepisów konwencji ${ }^{40}$. Jednakże sama konwencja nie została $\mathrm{w}$ dokumentach

${ }^{36}$ M. Pallemaerts, The Aarhus Convention at ten. Interactions and tensions between conventional international law and EU environmental law, Groningen 2011, passim.

37 Do państw-stron konwencji z Aarhus spoza UE należą: Albania, Armenia, Azerbejdżan, Białoruś, Bośnia i Hercegowina, Gruzja, Islandia, Kazachstan, Kirgistan, Liechtenstein, Monako, Czarnogóra, Norwegia, Mołdawia, Serbia, Szwajcaria, Tadżykistan, Macedonia Północna, Turkmenistan, Ukraina.

38 M. Szigeti Bonifert, Promoting Public Participation beyond the EU. The road to environmental democracy, [w:] Environmental Democracy and Law, s. 237 n.

39 Rio Declaration on Environment and Development, in Report of the United Nations Conference on Environment and Development, UN Doc. A/CONF.151/26 (Vol. I), 12 August 1992, Annex I, przeł. za: http://libr.sejm.gov.pl/tek01/txt/inne/1992.html (dostęp: 20.08.2021).

40 Tak też D. Torney, O. Gippner, op. cit., s. 286. 
tego programu wymieniona z nazwy, ze względu na jej demokratyczny i ściśle nawiązujący do ochrony praw człowieka charakter. Program Zarządzania Środowiskiem UE-Chiny przyczynił się do budowania potencjału ochrony środowiska przez wdrażanie narzędzi dialogu społecznego zarówno na poziomie krajowym, jak i lokalnym. Stworzono 15 lokalnych grup partnerskich z udziałem europejskich organizacji i administracji lokalnej w różnych prowincjach Chin. W ramach każdego $\mathrm{z}$ takich lokalnych projektów powstało konsorcjum zbudowane $\mathrm{z}$ pracowników administracji unijnej i chińskiej, przyporządkowane do jednego z czterech obszarów tematycznych projektu. Jednym z celów tego pilotażu było powielanie $\mathrm{w}$ przyszłości przepracowanych schematów zarządzania środowiskiem w dalszych prowincjach Chin ${ }^{41}$.

Władze chińskie cechuje dystans do nacisków prawnomiędzynarodowych w zakresie wdrażania standardów ochrony środowiska, a co za tym idzie przebudowy systemu instytucjonalnego, który jest decyzyjny w tym zakresie ${ }^{42}$. Zmiany w prawie, choć niespieszne, są jednak widoczne, szczególnie w ostatnim dziesięcioleciu. W okresie od 2014 roku do dzisiaj przeprowadzono znaczące reformy

41 Przykładem może być współpraca między chińskim miastem Jiaxing i europejską Hagą w ramach projektu Public Participation of Environmental Governance in the Jiaxing Model and its applicability in Zhejiang Province. Przetestowano tak zwany model Jiaxing zarządzania środowiskiem, a następnie implementowano go w ośmiu innych miastach chińskiej prowincji Zhejiang. Celem tych działań było budowanie świadomości społecznej i promowanie aktywnego udziału chińskiego społeczeństwa w zarządzaniu środowiskiem przez organizowanie paneli oceniających możliwe zagrożenia środowiska z prawem wskazywania zanieczyszczających przedsiębiorców. W programowaniu modelu Jiaxing podreślono wagę konsultacji społecznych: „democratic consultation is included in the governance mechanism. In the traditional environmental management model, management power is centred on the government, which is highly centralized and reacts slowly with higher running costs. Under the Jiaxing Model, social organisations and the public start to share management power with the government, shouldering the responsibility of management and cooperating with the government”, za: K. Wang, The „Jiaxing Model” and the „Polder Model”: A comparative study on public participation in environmental governance in Jiaxing and The Hague, International Association on Social Quality, The Hague-Amsterdam, 15.11.2014, https://www.socialquality.org/wp-content/uploads/import/2015/02/Final-Report-KaiWang-IASQ-25-November-2014.pdf (dostęp: 16.08.2021); L.J.G. van der Maesen, The position of citizens with regard to environmental protection: A contribution to a Chinese and European comparison based on reflections on the applied model by the Chinese city Jiaxing, Working Paper Series nr 14, International Association on Social Quality, 20.01.2015, https://www.socialquality.org/ wp-content/uploads/import/2015/02/Working-Paper-14-Environmental-Protection-Position-Citizens.pdf (dostęp: 16.08.2021).

42 Przykładowo, w sprawie ochrony klimatu Chiny zadeklarowały osiągnięcie neutralności klimatycznej (dopiero!) przed 2060 rokiem: „We aim to have CO2 emissions peak before 2030 and achieve carbon neutrality before 2060" - Statement by H.E. Xi Jinping President of the People's Republic of China at the General Debate of the 75th Session of The United Nations General Assembly, 22.09.2020, https://www.un.org/press/en/2020/ga12267.doc.htm (dostęp: 16.08.2021). 
wielu chińskich ustaw środowiskowych, na przykład ustawy w sprawie monitorowania jakości otaczającego powietrza ${ }^{43}$. W 2014 roku, po trzech latach prac i konsultacji, znacząco zrewidowano też chińskie Prawo o ochronie środowiska z 1972 roku $^{44}$. Jednym z największych osiągnięć nowelizacji było wyartykułowanie w tej ustawie, expressis verbis, szeregu zasad ogólnych międzynarodowego prawa ochrony środowiska, w tym zasad zrównoważonego rozwoju ${ }^{45}$. Artykuł 4 tego prawa w nowej wersji stanowi, że: „Ochrona środowiska jest podstawową polityką państwa. Rozwój gospodarczy musi być skoordynowany z ochroną środowiska"46. Zmiany przyjęte $w$ ramach tego przepisu są przełomowe, zważywszy, że w poprzedniej wersji z 1989 roku wyrażał on dokładnie przeciwną regułę: ,interes gospodarczy ponad wszystko". Nowy artykuł 5 chińskiego Prawa o ochronie środowiska zawiera także, kluczową dla demokracji środowiskowej, zasadę partycypacji społecznej w podejmowaniu decyzji środowiskowych ${ }^{47}$.

43 W.P. Alford, B.L. Liebman, Clean air, clean processes? The struggle over air pollution law in the People's Republic of China, „Hastings Law Journal” 52, 2001, nr 3, s. 703-748.

44 Zob. przypis 23; „China's NPC adopts revised Environmental Protection Law”, http:// ca.china-embassy.org/eng/zt/economy123/t1149908.htm (dostęp: 28.06.2021); L. Zhang, G. He, A.P.J. Mol, China's new environmental protection law: A game changer?, „Environmental Development" 2015, nr 13, s. 1-3; Mu Z., Bu S., Xue B., Environmental legislation in China: Achievements, challenges and trends, „Sustainability” 2014, nr 6, s. 8971; A.J. Liu, Ecological civilization and China's environmental legislation, China Popul. Resour. Environ. 2004, nr 14, s. 36-39.

45 Pełna wykładnia zrównoważonego rozwoju została przedstawiona przez kierownictwo partyjne 24 września 2013 r. na forum Leaders Dialogue of the United Nations „High-level Political Forum on Sustainable Development" w Nowym Jorku przez ministra spraw zagranicznych Chin Wang Yi. Podkreślił on wówczas, że „koncepcja zrównoważonego rozwoju jest dobrze znana w Chinach. Pojęcie harmonii pomiędzy człowiekiem a naturą oraz przywiązanie do zasady, zgodnie z którą nie spuszcza się wody ze stawu, by złowić rybę, stanowią zasadniczy element rodzimej tradycji”, por. Sustainable Development - The Road to Achieve Chinese Dream and Human Progress, remarks by H.E. Wang Yi Foreign Minister of the People's Republic of China at the Leaders Dialogue of the United Nations High-level Political Forum on Sustainable Development, New York, 24 September 2013, Ministry of Foreign Affairs of the People's Republic of China, 26 IX 2013, https://sdgs.un.org/statements/he-mr-wang-yi-11088 (dostęp: 17.08.2021).

46 „Article 4: The protection of environment is a basic national policy for China. The state shall adopt economic and technological policies and measures favorable for conservation and circulatory use of resources, protection and improvement of environment and harmony between human and nature, so as to coordinate economic and social development with the work of environmental protection [wyr. - J.B.-N.]".

47 „Article 5: Activities concerning environmental protection shall adhere to the following principles: according priority to protection, emphasis on prevention, integrated governance, public participation and liability assumption of damages [wyr. — J.B.-N.]". 


\section{Zasada partycypacji społecznej w chińskim prawie ochrony środowiska}

Historia instytucji prawnej: konsultacji społecznych ${ }^{48} \mathrm{w}$ Chinach, jest tak burzliwa jak dzieje samych Chin. W ciągu ostatnich sześćdziesięciu lat XX wieku konsultacje publiczne były jedynym znaczącym sposobem udziału społeczeństwa w procesie legislacyjnym. Pierwsza publiczna debata o charakterze konsultacji społecznych zorganizowana została przed przyjęciem konstytucji z 1954 roku i zaangażowała ponad $150 \mathrm{mln}$ obywateli, którzy zgłosili swoje uwagi ${ }^{49}$. Chociaż udział czynnika społecznego w tworzeniu prawa był żywy w teoretycznych koncepcjach demokratyzacji procesu legislacyjnego Peng Zhena (1902-1997) ${ }^{50}$ do 2000 roku, do konsultacji społecznych udostępniane były jedynie projekty, które ściśle dotyczyły interesów całego społeczeństwa albo miały znaczący wpływ na społeczeństwo ${ }^{51}$. W praktyce między 1954 a 2000 rokiem do publicznych konsultacji udostępniono tylko osiem ustaw ${ }^{52}$.

Z początkiem XXI wieku Komunistyczna Partia Chin zaczęła propagować model „demokratycznego, opartego na podstawach naukowych stanowienia

${ }^{48}$ Konsultacje społeczne to jedna $\mathrm{z}$ instytucji demokracji bezpośredniej (obok: referendum, inicjatywy ludowej i zgromadzenia ludowego). Udział w konsultacjach prowadzonych przez organy władzy publicznej jest formą aktywności społeczeństwa obywatelskiego. Celem konsultacji jest polepszenie jakości decyzji i legislacji. Do najważniejszych korzyści z prowadzenia konsultacji należą: lepsze rozpoznanie stanowisk adresatów proponowanego rozwiązania, poprawa lub nowe propozycje rozwiązań, upowszechnienie informacji o prowadzonych działaniach i większa akceptacja społeczna. Konsultacje społeczne mają charakter „miękkiego” narzędzia ze względu na to, że uzyskane stanowiska nie są wiążące dla organów władzy publicznej. Zatem uwagi zgłoszone w toku konsultacji społecznych mogą zostać uwzględnione w całości lub części albo nieuwzględnione w ogóle; por. Ł. Krzyżanowska, Ł. Faciejew, Partycypacja obywatelska w Polsce, Warszawa 2009; Wytyczne do przeprowadzania oceny wpływu oraz konsultacji publicznych w ramach rządowego procesu legislacyjnego, https://rcl.gov.pl/legislacja/wytyczne-do-przeprowadzania-ocenywplywu-oraz-konsultacji-publicznych-w-ramach-rzadowego-procesu-legislacyjnego/.

49 Zhu X., Wu K., Public participation in China's environmental lawmaking: In pursuit of better environmental democracy, ,Journal of Environmental Law” 2017, nr 29, s. 392.

50 Jeden z głównych architektów instytucji prawnych Chińskiej Republiki Ludowej w latach pięćdziesiątych XX wieku, a następnie po powrocie do polityki w latach osiemdziesiątych i dziewięćdziesiątych, kiedy to przeprowadził znaczące reformy chińskiego systemu prawa. Wpływ doktryny - socjalistycznego formalizmu Peng Zhena okazał się trwały i widoczny we współczesnym prawie chińskim, por. P.B. Potter, From Leninist Discipline to Socialist Legalism Peng Zhen on Law and Political Authority in the PRC, Palo Alto 2003, passim; Zhu Liyu, Yi Youlu, Pengzhen's democratic legislation thought and its impact on legislative practices, „Truth Seeking” 2008, $\mathrm{nr} 62$ (9).

51 L. Paler, China's legislation law and the making of a more orderly and representative legislative system, „The China Quarterly” 2005, nr 182, s. 301-318.

52 Zhu X., Wu K., op. cit., s. 392. 
prawa", który z czasem stał się obowiązującym standardem ${ }^{53}$. W 2000 roku w Chinach po raz pierwszy przyjęto ustawę o stanowieniu prawa (lifa fa), w której wprowadzono fakultatywne konsultacje społeczne ${ }^{54}$. W 2008 roku Rada Przewodniczących Stałego Komitetu Ogólnochińskiego Zgromadzenia Przedstawicieli Ludowych (Qanguo Renmin Daibiao Dahui Changwu Weiyuanhui, OZPL) ${ }^{55}$ wprowadziła obowiązkowe konsultacje społeczne w każdym procesie legislacyjnym. Znowelizowana w 2015 roku ustawa o stanowieniu prawa usankcjonowała tę zmianę. Obecnie art. 37 tej ustawy stanowi, że projekt aktu prawnego wraz z uzasadnieniem, po zamknięciu sesji Stałego Komitetu OZPL, powinien być udostępniony do konsultacji społecznych na 30 dni, chyba że przewodniczący Stałego Komitetu zdecyduje inaczej ${ }^{56}$. Ustawa w całej swej rozciągłości zbiera i kodyfikuje mechanizmy uwzględniające udział czynnika społecznego w procesie ustawodawczym. Przykładowo, artykuły 34 i 58 wymagają uwzględnienia opinii różnych sektorów przez organizowanie posiedzeń w celu wysłuchania opinii i wspólnych seminariów. Trzeba zauważyć, że spośród powszechnie znanych korzyści, jakie dają konsultacje społeczne, w procesie legislacyjnym w Chińskiej Republice Ludowej najbardziej eksponowane są: ulepszenie jakości legislacji opartej na wiedzy fachowej środowisk naukowych i badawczych oraz oczekiwany wzrost akceptacji społecznej, a co za tym idzie łatwiejsze egzekwowanie prawa ${ }^{57}$.

53 W 2007 roku na 17 Krajowym Zjeździe Komunistycznej Partii Chin sekretarz generalny partii $\mathrm{Hu}$ Jintao w swoim raporcie zaapelował o „naukowe i demokratyczne stanowienie prawa”. W sprawozdaniu przygotowanym na 18 Krajowy Zjazd KPCh w 2012 roku Hu Jintao postulował upowszechnienie partycypacji społecznej w procesie legislacyjnym. Obecny sekretarz generalny partii Xi Jinping w swoim raporcie przedstawionym na 4 plenarnej sesji Komitetu Centralnego w ramach 18 Zjazdu Krajowego KPCh podkreślił, że proces stanowienia prawa w ChRL jest oparty na podstawach naukowych i ma demokratyczny charakter.

54 Ang. Legislation Law of the People's Republic of China (Zhonghua renmin gongheguo lifa fa), ustawa ta uchwalona została na Trzeciej Sesji Plenarnej IX Ogólnochińskiego Zgromadzenia Przedstawicieli Ludowych 15 marca 2000 roku, składa się z 94 artykułów i reguluje tryb ustawodawczy w OZPL i jego Stałym Komitecie; więcej L. Paler, op. cit., s. 301; J. Rowiński, W. Jakóbiec, Parlament Chińskiej Republiki Ludowej, Warszawa 2008, s. 29, 32, 45.

$55 \mathrm{Na}$ temat struktury naczelnych organów państwa w ChRL zob. J. Rowiński, W. Jakóbiec, Parlament Chińskiej Republiki Ludowej..., s. 30; iidem, System konstytucyjny Chińskiej Republiki Ludowej, Warszawa 2006, s. 34 n.

56 Por. art. 37 ustawy o stanowieniu prawa: ,For a bill on the agenda of a session of the Standing Committee, the draft law and an explanation of the drafting and amendment thereof, among others, shall, after the end of the session of the Standing Committee, be released to the public to solicit opinions, unless a decision not to release the same is made at the Chairmen's Meeting. The period during which public opinions are solicited on the same shall not be less than 30 days. Information on the solicitation of opinions shall be released to the Public".

57 Zhu Jingwen, Public participation in law-making in the PRC, [w:] Lawmaking in the People's Republic of China, red. J. Otto et al., London-Leiden 2000, s. 141-156; R. Peerenboom, The Long March Towards the Rule of Law, Cambridge 2002, s. 242-47. 
Tabela 1. Rozwój instytucji konsultacji społecznych w procesie legislacyjnym Ogólnochińskiego Zgromadzenia Przedstawicieli Ludowych (OZPL)

\begin{tabular}{|c|c|c|c|}
\hline & Podstawa prawna & Przykłady & Charakterystyka \\
\hline 1954-2000 & brak & $\begin{array}{l}\text { konstytucja z } 1954 \text { roku, } \\
\text { nowelizacja konstytucji } \\
\text { z } 1982 \text { roku, Prawo } \\
\text { umów z } 1999 \text { roku }\end{array}$ & $\begin{array}{l}\text { konsultowano nieliczne } \\
\text { wybrane projekty aktów } \\
\text { prawnych korespondują- } \\
\text { cych z ,interesami ludu" }\end{array}$ \\
\hline $2000-2008$ & $\begin{array}{l}\text { ustawa o stanowieniu } \\
\text { prawa (lifa fa) z } 15 \text { maca } \\
2000 \text { roku - ważne } \\
\text { projekty aktów prawnych } \\
\text { mogły być udostępnione } \\
\text { do konsultacji społecz- } \\
\text { nych decyzją Rady Prze- } \\
\text { wodniczących Stałego } \\
\text { Komitetu OZPL }\end{array}$ & $\begin{array}{l}\text { ustawa o prawie własno- } \\
\text { ści z } 2007 \text { roku, Prawo } \\
\text { pracy z } 2007 \text { roku, } \\
\text { ustawa o promocji za- } \\
\text { trudnienia z } 2007 \text { roku, } \\
\text { nowelizacja ustawy } \\
\text { o gospodarce wodnej } \\
2008 \text { roku }\end{array}$ & $\begin{array}{l}\text { wyraźny wzrost liczby } \\
\text { udostępnianych pro- } \\
\text { jektów i udzielonych } \\
\text { komentarzy; najwięcej } \\
\text { opinii, ponad } 200 \text { tys., } \\
\text { otrzymał projekt Prawa } \\
\text { pracy }\end{array}$ \\
\hline 2008-teraz & $\begin{array}{l}\text { Rada Przewodniczących } \\
\text { Stałego Komitetu OZPL } \\
\text { na } 11 \text { sesji OZPL zdecy- } \\
\text { dowała o udostępnianiu } \\
\text { wszystkich projektów } \\
\text { z wyjątkiem tych „,nie- } \\
\text { odpowiednich”; ustawa } \\
\text { o stanowieniu prawa } \\
\text { z } 2015 \text { roku usankcjono- } \\
\text { wała tę zmianę }\end{array}$ & $\begin{array}{l}\text { prawo patentowe z } 2008 \\
\text { roku, ustawa o odpo- } \\
\text { wiedzialności deliktowej } \\
\text { z } 2009 \text { roku, Prawo } \\
\text { ubezpieczeń społecznych } \\
\text { z } 2010 \text { roku, ustawa } \\
\text { o podatku dochodowym } \\
\text { od osób fizycznych } \\
\text { z } 2011 \text { roku, ustawa } \\
\text { o promocji ekologicznej } \\
\text { produkcji z } 2012 \text { roku }\end{array}$ & $\begin{array}{l}\text { wzrost liczby udostęp- } \\
\text { nianych projektów; } \\
\text { najbardziej komentowa- } \\
\text { no nowelizację Prawa } \\
\text { pracy - } 550 \text { tys. ko- } \\
\text { mentarzy }\end{array}$ \\
\hline
\end{tabular}

Źródło: Zhu X., Wu K., Public participation in China's environmental lawmaking: In pursuit of better environmental democracy, „Journal of Environmental Law” 2017, nr 29, s. 393.

Zasada partycypacji społecznej została uregulowana w prawie chińskim, zarówno wśród zasad procesu legislacyjnego, w art. 5 wspomnianej ustawy o stanowieniu prawa, jak i wśród zasad ochrony środowiska, we wskazanym już art. 5 Prawa ochrony środowiska ${ }^{58}$. Wobec ograniczonych w Chinach możliwości rozwoju debaty publicznej na temat kwestii społecznych i politycznych dyskusja publiczna wokół problemów ochrony środowiska jest akceptowana i dobrze tolerowana przez władze. Stąd też w zapoczątkowany w 2011 roku i trwający blisko trzy lata proces konsultacji społecznych w sprawie nowego prawa ochrony środowiska zaangażowanych było aż 112 chińskich NGO's ${ }^{59}$. Chociaż trzeba zauważyć, że tylko $11 \mathrm{z}$ nich ma bardziej rozbudowaną strukturę, świadczy pomoc prawną i zajmuje się rzecznictwem politycznym ${ }^{60}$.

\footnotetext{
58 Zob. przypisy 23 i 44.

59 Zhu X., Wu K., op. cit., s. 410.

60 Ibidem.
} 
Konstrukcja przepisów rozdziału V Prawa ochrony środowiska dotyczących dostępu do informacji i partycypacji społecznej w ich najnowszej wersji z 24 kwietnia 2014 roku w pełni odpowiada europejskim standardom. Trzeba jednak wyraźnie podkreślić, że implementacja tych przepisów w Chinach przebiega zupełnie inaczej niż w Europie, ze względu na wiele uwarunkowań politycznych, kulturowych i społecznych, o których w niniejszej pracy była mowa. Chodzi przede wszystkim o wciąż niewielki (w porównaniu $\mathrm{z}$ tradycjami europejskimi) realny wpływ ruchu obywatelskiego i organizacji pozarządowych na zarządzanie środowiskiem w Chinach oraz bardzo niski poziom akceptacji, a nawet świadomości potrzeby ochrony środowiska wśród przedsiębiorców. Na poziomie normatywnym art. 53 chińskiego Prawa ochrony środowiska gwarantuje obywatelom, osobom prawnym i innym organizacjom dostęp do informacji o środowisku, mają oni też prawo udziału w podejmowaniu decyzji środowiskowych i prawo nadzoru nad działaniami w zakresie ochrony środowiska. Właściwe organy administracji lokalnej oraz wydziały administracji odpowiedzialne za nadzorowanie ochrony środowiska są zobowiązane ten dostęp do informacji o środowisku zapewnić. Zgodnie z literą prawa władze lokalne wspierają także rozwój procedur służących partycypacji społecznej, umożliwiając społeczeństwu obywatelskiemu udział i nadzór nad pracami dotyczącymi ochrony środowiska ${ }^{61}$.

\section{Podsumowanie}

Wyniki badań nad prawem i społeczeństwem Chin skłaniają nas do spojrzenia na to państwo, jego formę rządów i społeczeństwo obywatelskie inaczej, niż przywykliśmy to robić w Europie, i uznania możliwości istnienia rozmaitych form, które w naszej społeczności międzynarodowej winny się opierać jedynie na pewnych uniwersalnych i ponadkulturowych zasadach ${ }^{62}$. Bez wątpienia to tradycje prawne, doświadczenia historyczne i polityczne determinują kształt instytucji prawnych państwa.

61 Por. „Chapter V Information Disclosure and Public Participation. Article 53: Citizens, legal persons and other organizations shall have the right to obtain environmental information, participate and supervise the activities of environment protection in accordance with the law. The competent environmental protection administrations of the people 's governments at various levels and other departments with environmental supervision responsibilities shall disclose environmental information pursuant to the law, improve public participation procedures, and facilitate citizens, legal persons and other organizations to participate in, and supervise [wyr. - J.B.-N.], environmental protection work".

62 R.Y. Jennings, Universal international law in a multicultural world, [w:] International Law and the Grotian Heritage: A Commemorative Colloquium on the Occasion of the Fourth Centenary of the Birth of Hugo Grotius, The Hague 1985, s. 189; C.G. Weeramantry, Universalising International Law, Leiden 2004, passim. 
Konstruktywny dialog między kulturami i cywilizacjami jest zasadą Organizacji Narodów Zjednoczonych i tworzy podstawę dobrej współpracy państw. Nie ma przecież jednoznacznych badań, które wskazywałyby na to, że azjatyckie wartości uniemożliwiają skuteczne wprowadzanie elementów demokracji, zwłaszcza gdy chodzi o zarządzanie wspólnym dobrem, jakim jest środowisko naturalne człowieka. W Chinach paradoksalnie — ze względu na lata zaniedbań - to właśnie ochrona środowiska jest dziedziną, w której międzynarodowe standardy demokracji środowiskowej dobrze się przyjmują. Kluczowe znaczenie dla przeniesienia do Chin wzorców zarządzania środowiskiem i elementów demokracji środowiskowej wypracowanych przez ONZ, a następnie skodyfikowanych w konwencji z Aarhus miały najpierw implementacja zasady 10 Deklaracji z Rio w sprawie Środowiska i Rozwoju z 1992 roku, a następnie realizacja Programu Zarządzania Środowiskiem UE-Chiny (2010-2015). Na tych podstawach ukształtował się w Chinach model partycypacji społecznej w podejmowaniu decyzji środowiskowych. Prawo chińskie wobec braku rodzimego wzorca z powodzeniem recypowało $\mathrm{w}$ tym zakresie standard europejski, który na poziomie wykładni został dostosowany do obowiązującego tam otoczenia prawnego, stąd w Chinach fundamentem demokracji środowiskowej, analogicznie jak w Europie, stały się trzy prawa obywatelskie do: informacji, partycypacji i sprawiedliwości, w obszarze ochrony środowiska. Znaczący wpływ na rozwój świadomości ekologicznej społeczeństwa obywatelskiego w Chinach wywarła społeczność międzynarodowa, przede wszystkim organizacje międzyrządowe, ale także międzynarodowe NGO's, które przez działania oddolne, na poziomie lokalnym poruszyły opinią publiczną w kwestiach ekologicznych.

\section{Bibliografia}

Alford W.P., Liebman B.L, Clean air, clean processes? The struggle over air pollution law in the People's Republic of China, „Hastings Law Journal” 52, 2001, nr 3.

Asian Judges Symposium on Environmental Decision Making, the Rule of Law, and Environmental Justice: The Proceedings of the Symposium, Asian Development Bank 2011, http://hdl.handle. net/11540/2938.

Bándi G., Introduction into the concept of "environmental democracy", [w:] Environmental Democracy and Law, red. G. Bándi, Groningen-Amsterdam 2014.

Brook T., Auto-Organization in Chinese Society, [w:] Civil Society in China, red. T. Brook, B.M. Frolic, New York-London 1997.

Dąbrowski P., Myśl polityczno-prawna starożytnych Chin. Próba syntezy, „Gdańskie Studia Azji Wschodniej" 2012, nr 2.

Dargas-Draganik M., Idee i zasady konstytucyjne chińskiego porządku prawnego, Warszawa 2017.

Gawlikowski K., Charakter i dynamika ,,reform Deng Xiaopinga”, 4.06. 2016, https://www.swps.pl/ nauka-i-badania/materialy-ccaw/2445-charakter-i-dynamika-reform-deng-xiaopinga. 
Gawlikowski K., Formowanie społeczeństwa obywatelskiego w Chinach w XX w., [w:] Chiny: rozwój społeczeństwa i państwa na przełomie XX i XXI wieku, red. K. Gawlikowski, K. Tomala, Warszawa 2002.

Gawlikowski K., Jednostka w tradycji konfucjańskiej, [w:] Indywidualizm a kolektywizm, red. K. Gawlikowski, J. Jedlicki, J. Kochanowicz, T. Kowalik, K. Obuchowski, J. Reykowski, J. Szacki, W. Wesołowski, Warszawa 1999.

Gawlikowski K., Rola spoleczeństwa obywatelskiego w najnowszych dziejach Chin, [w:] Region Azji i Pacyfiku w latach 1985-2015, red. A. Jarczewska, J. Zajączkowski, Warszawa 2016.

Gawlikowski K., Zachodni indywidualizm a konfucjańska apoteoza wspólnoty i tożsamości grupowej, „Azja-Pacyfik” 23, 2020.

Gawlikowski K., Ławacz M., Wielkie przemiany w Chinach. Próba bilansu reform Deng Xiaopinga, Warszawa 2012.

Harrison L.E., Who Prospers? How cultural values shape economic and political success, New York 1992.

Huntington S., The clash of civilizations?, „Foreign Affairs” 72, 1993, nr 3.

Hongming Gu, Duch narodu chińskiego, przeł. J. Targowski, Kraków 1928.

Jelonek A.W., Confucianism - Asian values and liberal democracy, [w:] China: Confucian Tradition - Towards the New Century, red. A.W. Jelonek, B.S. Zemanek, Kraków 2008.

Jingwen Z., Public participation in law-making in the PRC, [w:] Lawmaking in the People's Republic of China, red. J. Otto et al., London-Leiden 2000.

Konfucjusz, Szy-cing. Księga Pieśni, przeł. M. Szlenk-Iliewa, Warszawa 1995.

Krzyżanowska Ł., Faciejew Ł., Partycypacja obywatelska w Polsce, Warszawa 2009.

Kuhn B., Changing spaces for civil society organisations in China, „Open Journal of Political Science" 2018, nr 8.

Liu A.J., Ecological civilization and China's environmental legislation, China Popul. Resour. Environ. 2004, nr 14.

Liyu Z., Youlu Y., Pengzhen's democratic legislation thought and its impact on legislative practices, „Truth Seeking” 62, 2008, nr 9.

Maesen L.J.G. van der, The position of citizens with regard to environmental protection: A contribution to a Chinese and European comparison based on reflections on the applied model by the Chinese city Jiaxing, Working Paper Series nr 14, International Association on Social Quality, 20.01.2015, https://www.socialquality.org/wp-content/uploads/import/2015/02/ Working-Paper-14-Environmental-Protection-Position-Citizens.pdf.

$\mathrm{Mu} \mathrm{Z} ., \mathrm{Bu}$ S., Xue B., Environmental legislation in China: Achievements, challenges and trends, „Sustainability” 2014, nr 6.

Najam A., Papa M., Taiyab N., Global Environmental Governance: A Reform Agenda, Winnipeg 2006.

Paler L., China's legislation law and the making of a more orderly and representative legislative system, „The China Quarterly” 2005, nr 182.

Pallemaerts M., The Aarhus Convention at Ten. Interactions and tensions between conventional international law and EU environmental law, Groningen 2011.

Peerenboom R., The Long March Towards the Rule of Law, Cambridge 2002.

Pohl K.-H., Life and death in East and West - Montaigne's views on death compared to attitudes found in the Chinese tradition, „Azja-Pacyfik” 21, 2018.

Pohl K-H., "The World shared by all alike" (天下为公) —China: Between Confucianism, Marxism and Democracy, „Azja-Pacyfik” 22, 2019.

Potter P.B., From Leninist Discipline to Socialist Legalism Peng Zhen on Law and Political Authority in the PRC, Palo Alto 2003.

Rowiński J., Jakóbiec W., Parlament Chińskiej Republiki Ludowej, Warszawa 2008. 
Rowiński J., Jakóbiec W., System konstytucyjny Chińskiej Republiki Ludowej, Warszawa 2006.

Sadowski M., Konfucjusz, [w:] Leksykon myślicieli politycznych i prawnych, red. E. Kundera, M. Maciejewski, Warszawa 2009.

Sen A., How does culture matter?, [w:] Culture and Public Action, red. V. Rao, M. Walton, Palo Alto 2004.

Shieh S., Knutson S., Special Report The Roles and Challenges of International NGOs in China's Development, „China Development Brief” 55, 2012.

Siu Inboden R., China at the UN: Choking Civil Society, „Journal of Democracy” 32, 2021, nr 3.

Stępień M., Chińskie marzenie o konstytucjonalizmie, Kraków 2015.

Szigeti Bonifert M., Promoting Public Participation beyond the EU. The road to environmental democracy, [w:] Environmental Democracy and Law, red. G. Bándi, Groningen-Amsterdam 2014.

Tan Y., How the WTO Changed China. The Mixed Legacy of Economic Engagement, https://www. foreignaffairs.com/articles/china/2021-02-16/how-wto-changed-china.

Torney D., Gippner O., China: Deepening cooperation on climate and environmental governance, [w:] European Union External Environmental Policy. Rules, Regulation and Governance Beyond Borders, red. C. Adelle, K. Biedenkopf, D. Torney, Cham 2018.

Tylkowski M., Gu Hongming prekursorem idei fuzji cywilizacji. Konfucjanizm jako ratunek dla Zachodu i świata, Warszawa 2021.

Wang K., The "Jiaxing Model" and the "Polder Model": A comparative study on public participation in environmental governance in Jiaxing and The Hague, International Association on Social Quality, The Hague-Amsterdam, 15.11.2014, https:/www.socialquality.org/wp-content/ uploads/import/2015/02/Final-Report-Kai-Wang-IASQ-25-November-2014.pdf.

Yang Y., How do EU norms diffuse? Rule of law promotion in EU-China cooperation on environmental governance, „Journal of European Integration” 39, 2017, nr 1.

Zhang B., Cao C., Gu J., Liu T., A new environmental protection law, many old problems? Challenges to environmental governance in China, „Journal of Environmental Law” 2016, $\mathrm{nr} 28$.

Zhang L., He G., Mol A.P.J., China's new environmental protection law: A game changer?, „Environmental Development" 2015, nr 13.

Zhu X., Wu K., Public participation in China's environmental lawmaking: In pursuit of better environmental democracy, ,Journal of Environmental Law” 2017, nr 29. 